\title{
Effects of variable-row-spacing harvesting picker platform scraping plates on cotton fiber quality and quantity
}

\section{Placas de raspagem nas plataformas de colheita picker vrs e perdas qualitativas e quantitativas de algodão}

\author{
Cíntia Michele de Campos Baraviera ${ }^{1}$; Renildo Luiz Mion ${ }^{2 *}$; \\ Hiago Henrique Rocha Zanetoni ${ }^{3}$; Nayra Fernandes Aguero ${ }^{4}$; \\ Renato Tillmann Bassini ${ }^{5}$; Carlos Alberto Viliotti ${ }^{2}$
}

\begin{abstract}
There have been increasing demands for high-quality cotton fibers that meet the textile industry quality standards. Concurrently, there have been efforts to reduce contaminants during harvesting to reduce harvesting costs. The goal of this research was to evaluate the efficiency of the picker platform with Variable-Row-Spacing (VRS) for harvesting cotton in narrow rows, over two harvest seasons in two regions within the state of Mato Grosso, Brazil. In this study, how the presence vs. absence of scraping plates and variations in travel speed was related to quantifiable levels of impurities the harvested fibers was examined. The research was divided into three experiments (Exp. I, II, and III), using cotton varieties FM 975 WS, IMA 5672 B2 RF, and IMA 5675 B2 RF, with row spacing of $0.45 \mathrm{~m}$. The experimental design was randomized blocks, in a $2 \times 3$ factorial design, using the presence/absence of the plate and three speeds $\left(0.61,1.0\right.$, and $\left.1.42 \mathrm{~m} \cdot \mathrm{s}^{-1}\right)$, with seven repetitions, totaling 42 experimental plots. The plot size was $108 \mathrm{~m}^{2}(3.6 \times 30 \mathrm{~m})$. The data were analyzed using the $\mathrm{F}$ test in ANOVA and the post-hoc Tukey test $(\mathrm{p}<0.05)$. The results showed that scraping plates increased the number of stems and cones, and reduced the harvest efficiency of cotton planted in narrow rows in the region of Sorriso-MT during the 2013/2014 harvest. For the 2014/2015 harvest, the highest speed and the presence of the scraping plates increased the number of cones in the cotton samples. In the experiment conducted in Serra da Petrovina, the removal of the scraping plates decreased the amount of cones in the harvested cotton.

Key words: Cotton planted in narrow rows. Mechanical harvesting. Harvest efficiency.
\end{abstract}

\section{Resumo}

A demanda por fibras de algodão de alta qualidade para atender a demanda da indústria têxtil e a busca incessante para reduzir a presença de contaminantes no momento da colheita de forma a contribuir para a redução dos custos. O objetivo da pesquisa foi avaliar a eficiência da plataforma Picker VRS (unidades de espaçamento variável) de colheita do algodão adensado no Estado de Mato Grosso, com e sem placas de raspagem, variando a velocidade de deslocamento, quantificando as impurezas nesse processo e

1 Enga Agra ${ }^{\mathrm{a}}$, M.e em Engenharia Agrícola, Universidade Federal do Mato Grosso, UFMT, Campus Universitário de Rondonópolis, Rondonópolis, MT, Brasil. E-mail: cih_baraviera@hotmail.com

2 Eng ${ }^{\circ}$ Agrícolas, Profs. Associados do Curso de Engenharia Agrícola e Ambiental, UFMT, Campus Universitário de Rondonópolis, Rondonópolis, MT, Brasil. E-mail:renildomion@gmail.com; cmagrao@yahoo.com.br

3 Eng ${ }^{\circ}$ Agrícola, UFMT, Campus Universitário de Rondonópolis, Rondonópolis, MT, Brasil. E-mail: hiago.zanetoni@hotmail. com

4 Enga Agrícola, M.e, UFMT, Campus Universitário de Rondonópolis, Rondonópolis, MT, Brasil. E-mail: nayra_fa@hotmail.com

5 Prof. M.e, Curso de Engenharia Mecânica, UFMT, Campus Universitário de Rondonópolis, Rondonópolis, MT, Brasil. E-mail: renatobassini@ufmt.br

* Author for correspondence 
avaliando a qualidade extrínseca e intrínseca da fibra colhida. A pesquisa foi dividida em 3 experimentos (Exp. I, II e III). As variedades de algodão utilizadas foram FM 975 WS, IMA 5672 B2 RF e IMA 5675 B2 RF, com espaçamentos entre linhas de $0,45 \mathrm{~m}$. O delineamento experimental utilizado foi de blocos casualizados, em esquema fatorial $2 \times 3$, sendo presença e ausência da placa e três velocidades de trabalho $\left(0,61 ; 1,0\right.$ e $\left.1,42 \mathrm{~m} \cdot \mathrm{s}^{-1}\right)$, com sete repetições, totalizando 42 parcelas experimentais. A dimensão das parcelas foi de $108 \mathrm{~m}^{2}(3,6 \times 30 \mathrm{~m})$. Os resultados obtidos foram submetidos à análise de variância por meio do Teste de F, e quando significativos submetidos ao teste de Tukey, a $5 \%$ de probabilidade. As placas de raspagem aumentaram a quantidade de caule, casquinhas e reduziu a eficiência na colheita do algodão adensado na região de Sorriso-MT na safra 2013/2014. Para a safra 2014/2015 a maior velocidade e a presença das placas de raspagem aumentaram a quantidade de casquinhas nas amostras de algodão em caroço. No experimento realizado na Serra da Petrovina a retirada das placas de raspagem diminuiu a quantidade de cascas no algodão colhido.

Palavras-chave: Algodão adensado. Colheita mecanizada. Eficiência de colheita.

\section{Introduction}

Cotton (Gossypium hirsutum L.) is one of the primary economic crops in Brazil. The country is the world's fifth largest cotton producer, with 4.4 million tons produced in the 2013/2014 harvesting season. This production is concentrated in the West Center, where $66 \%$ of the total cotton production was reported. The State of Mato Grosso leads the national production with a planted area of almost 600,000 hectares, where conventional cotton is grown in $90 \%$ of the sown area, with row spacing between 0.76 and $0.90 \mathrm{~m}$, when sown after soybeans. The remaining area is used as a narrow row system, with spacing between 0.40 and $0.76 \mathrm{~m}$ (CONAB, 2014).

The picking spindles that remove the bolls from the plants can leave behind contaminants, such as leaves, cones, branches, and soil particles, that influence the quality of the cotton fibers (ALVAREZ et al., 1990; BAKER et al., 1994). The globalization of the production of cotton and related textile products has increased the demand for high quality fibers to supply to the textile industry. There is also increased competition from the production of synthetic fibers that do not contain contaminants and are not prone to degradation (SMITH et al., 2008). Therefore, it is necessary to determine which harvesting methods can maintain or increase the competitiveness of the cotton farming sector, as well as the farmers.

The spindle picker harvesters are able to extract the cotton without touching the cones. The spindles of these harvesters operate by curling around the cotton and extracting it from the capsule. The cotton is subsequently shaken off the spindles by rubber shredders and blown the machine basket (BELOT and VILELA, 2006).

To harvest cotton sown in narrow rows, using the VRS (variable-rows-spacing) picker system, the plants of one row are cut at a height of 0.05 to $0.15 \mathrm{~m}$ and vertically transported to join the non-cut plants in the adjacent row (SOFIATTI, 2011), where the cotton bolls are extracted.

Mechanized cotton harvesting is one of the most critical aspects of crop management because the high production costs affect the fiber quality. There have been many efforts to find a system that is not only efficient but also reduces impurities in the harvested cotton fibers (FAIRCLOTH et al., 2004).

This study hypothesized that the presence of scraping plates on the cotton picker platforms would increase the quality and decrease the losses of cotton fibers because these plates reduce the space through which the plant mass enters the platform at the moment of harvest. The goal of this research was to evaluate the efficiency of the picker platform with VRS on the mechanical harvesting of narrow-row cotton, over two harvest seasons in two regions within the Brazilian state of Mato Grosso. To evaluate this, we examined the effects of the presence vs. absence of scraping plates and variations in travel speed on the harvested fiber. 


\section{Material and Methods}

Three experiments were conducted in the Serra da Petrovina region in southern Mato Grosso and in the northern part of the state, in the municipality of Sorriso. Crops from the 2013/2014 and 2014/2015 harvests were examined.
The experimental design was randomized blocks, in a $2 \times 3$ factorial design, for all experiments. The tests were made on the two operation methods (presence vs. absence of scraping plates) (Figure $1)$, and at three harvesting speeds $(0.61,1.0$, and $\left.1.42 \mathrm{~m} \cdot \mathrm{s}^{-1}\right)$, with seven replications, totaling 42 experimental plots, each with an area of $108 \mathrm{~m}^{2}(3.6$ $\times 30 \mathrm{~m})$.

Figure 1. (A) Harvester with picker variable-row-spacing harvesting platfortm used in the experiments and (B) Scraping plates removed from the harvesting units.

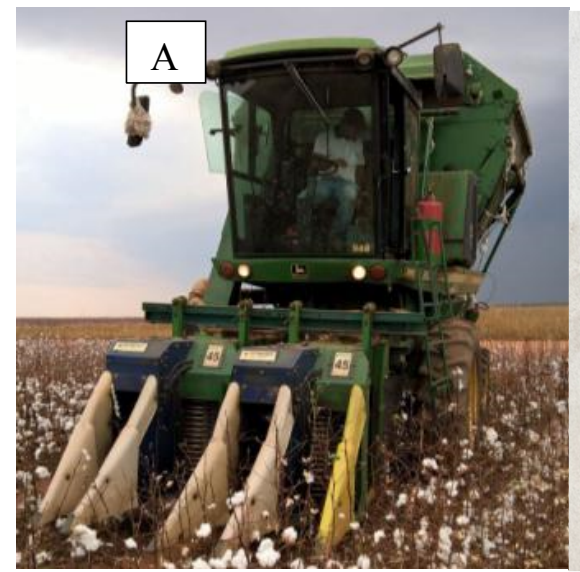

Agrotech ${ }^{\circledR}$ narrow row cotton was used in all experiments. The cotton variety FM 975 WS was used for the experiment in the Sierra Petrovina region. In the Sorriso region, for the 2013/2014 crop, the cotton variety was IMA 5672 B2RF, and for the 2014/2015 crop, the cotton variety was IMA 5675 B2RF. For all three harvests, we used a John Deere cotton harvester, model 9930, with a VRS platform with four lines spaced $0.45 \mathrm{~m}$ apart. The harvester was driven by the same operator for all experiments.

To determine the displacement speed, a length of $50 \mathrm{~m}$ was demarcated and the time that the machine took to cover this distance was recorded. Three replicates were performed to obtain the machine's average time of displacement along $50 \mathrm{~m}$.

The moisture from the cotton field was instantly determined at the time of harvest, using calibrated

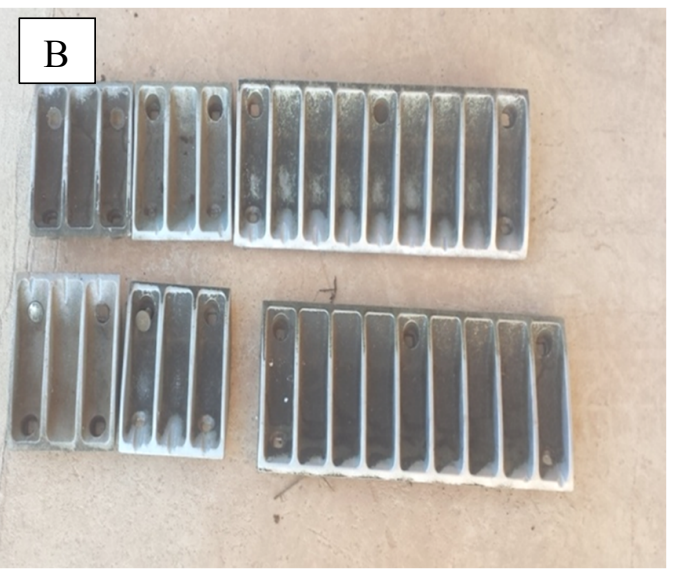

Hygron ${ }^{\circledR}$ measuring equipment. Data regarding the number and height of plants, height of the first boll, and number of bolls per plant were obtained from within the delimited area.

Before the harvester passed through the plots, the agronomic characteristics of each plot were recorded (Table 1), as well as the number of plants in the rows, the number of open, semi-open, and closed bolls per plant, the maximum plant height, and the height of insertion of the first boll. A measuring tape was used to measure the bolls on each plant and the insertion height of the first boll for three randomly selected plants; these measurements were then averaged.

Productivity and pre-harvest loss were estimated prior to harvesting using a known area of $4.5 \mathrm{~m}^{2}(5.0$ $\times 0.9 \mathrm{~m}$ ), within which all the cotton was manually harvested. Pre-harvest losses were estimated as the 
weight of cotton on the soil surface. Within the same area of $4.5 \mathrm{~m}^{2}$, post-harvest losses were estimated by manually harvesting the cotton that remained on the plant, as well as the cotton that fell onto the soil surface as a result of harvester activity. All samples were packed in plastic and raffia bags, according to the size of the samples, and were identified with tags and stored for analysis.

Table 1. Agronomic characteristics of the experimental area located at Serra da Petrovina and Sorriso regions - MT, during the crops $(2013 / 2014)$ and $(2014 / 2015)$.

\begin{tabular}{|c|c|c|c|}
\hline Agronomic characteristics & $\begin{array}{c}\text { Serra da Petrovina } \\
(2013 / 2014)\end{array}$ & $\begin{array}{l}\text { Sorriso-MT } \\
(2013 / 2014) \\
\end{array}$ & $\begin{array}{l}\text { Sorriso-MT } \\
(2014 / 2015)\end{array}$ \\
\hline Cultivar & FM $975 \mathrm{WS}$ & IMA 5672 B2RF & IMA 5675 B2RF \\
\hline Productivity (kg ha-1) & 5,796 & 1,845 & 3,089 \\
\hline Number of plants per hectare (thousand) & 108.88 & 128.88 & 166.44 \\
\hline Average plant height $(\mathrm{m})$ & 1.07 & 0.94 & 0.92 \\
\hline Average height of first boll (m) & 0.30 & 0.25 & 0.26 \\
\hline \multirow{3}{*}{$\begin{array}{lll}\text { Average } & \text { Number } & \text { Open } \\
\text { of bolls } & & \text { Semi-open } \\
& \text { Closed }\end{array}$} & 8 & 4.00 & 6.00 \\
\hline & 0.08 & 0.15 & 0 \\
\hline & 0.01 & 0.03 & 0 \\
\hline
\end{tabular}

The samples collected from the harvester basket during each treatment were weighed. The impurities were manually separated into two categories (stem and cones) and weighed on an analytical scale to quantify the amount of contaminants present in the fibers. The percentage of stems and the percentage of cones were calculated as the ratio of the weight of each impurity to the total sample weight.

After the separation and identification of impurities, these samples were taken to the IMAMT experimental station in Primavera do LesteMT, processed in a ginning machine with 20 saws, and sent to the UNICOTTON laboratory in Primavera do Leste-MT to determine the fiber quality using the HVI (High Volume Instrument). The following characteristics were measured: short fiber index (SFC), fiber length uniformity index in $\%$ (IU), fiber length in mm (UHM), fiber strength in $\mathrm{gf} /$ tex (STR), micronaire index (MIC), degree of yellowing $(+b)$, reflectance degree of the fibers in $\%$ $(\mathrm{Rd})$, area occupied by the impurities relative to the total sample area in \% (Area).

Harvesting efficiency was calculated according to the equation provided by RODRIGUEZ (1977) (Equation 1):

$$
\text { Picker Eficiency }=\frac{100 \times \text { algodão colhido }}{\text { algodão colhido }+ \text { perdas pós colheita }}
$$
where,

Harvested cotton - productivity $\mathrm{kg} \cdot \mathrm{ha}^{-1}$, and

Post-harvest losses - results in $\mathrm{kg} \cdot \mathrm{ha}^{-1}$.

Efficiency was calculated as the proportion of the losses incurred during harvesting and crop productivity.

The data were analyzed using the $\mathrm{F}$ test in ANOVA and the post-hoc Tukey test $(p<0.05)$ using ASSISTAT 7.7 (SILVA, 2014).

\section{Results and Discussion}

Of all the variables analyzed, only the percentage of stems was significantly related to the presence/ absence of the scraping plates, with the highest percentage of stems $(0.44 \%)$ occurring when scraping plates were used and the lowest percentage of stems $(0.30 \%)$, occurring when scraping plates were not used, in the region of Serra da Petrovina - MT, during the 2013/2014 crop (Table 2). 
Contamination with stems within a batch of ginned cotton causes technical problems in spinning mills and weaving industries (CHANSELME; RIBAS, 2010). This can pose significant production losses during the weaving process from interruptions in the open-end process, different absorption of dye by stem fragments and, consequently, a lower quality end product.

The harvesting speed did not affect the studied variables in the 2013/2014 crop in Sorriso. However, a larger percentage of stems $(0.38 \%)$ were obtained in samples from the harvester basket in the absence of the scraping plate, than when a scraping plate was used (Table 2). The lowest incidence of stems in the samples occurred with the absence of the scraping plate, probably because of machine conditions and the plant architecture, productivity, and defoliation characteristics of this cotton variety. The lowest percentage of cones $(1.14 \%)$ was found in the absence of the scraping plates (Table 2).

The most efficient $(90.38 \%)$ harvest did not use scraping plates in the collection units (Table 2). Williford et al.(1994) reported that spindle harvesters typically have harvest efficiencies between $85 \%$ and $90 \%$, but can reach $95 \%$ efficiency.

During the agricultural year of 2014/2015 in Sorriso, the highest percentage of cones $(2.65 \%)$ was found when scraping plates were used and the lowest percentage $(2.16 \%)$ was found when the scraping plates were not used (Table 2). In addition, the lowest percentage of contaminants within the cones $(2.17 \%)$ occurred at speed $1\left(0.61 \mathrm{~m} \cdot \mathrm{s}^{-1}\right)$.
Several characteristics of cotton cultivars can influence the amount of impurities in the harvested cotton and the percentages of crop losses. Belot and Vilela (2006) showed that there were differences in how impurities in various cultivars adhered to seed cotton in the open capsule. Baker et al. (1994) and Mangialardi Junior and Anthony (1998) stated that harvesting and cotton processing procedures may have significant effects on fiber characteristics such as length, impurities, color, and non-fibrous material, which interfere with the manufacturing and quality of the threads and, consequently, on the weaving and dyeing processes.

To reduce the harvesting time, producers use a higher harvester displacement speed. However, for the 2014/2015 crop in Sorriso, the lowest speed $\left(0.61 \mathrm{~m} \square \mathrm{s}^{-1}\right)$ left fewer cones in the cotton samples (Table 2). Bruneta (2005) reported that the appropriate speed for cotton harvesting should be determined based on plant characteristics and the operator's productivity and skills.

During the 2013/2014 Serra da Petrovina harvest, there were no significant relationships between displacement speed and the presence/absence of scraping plates and the variables of MIC, IU, UHM, Area, STR, +b, SFC, and Rd.

There was an isolated effect between MIC and IU and the presence/absence of scraping plates (Table 3). MIC is a measurement of the relative maturity and fineness of the fiber. Low MIC values may result from the presence of immature fibers, whereas high MIC values indicate decreased thread strength. Products with MIC values below 3.7 and above 4.2 typically bring in less revenue (AMPA, 2014). 
Table 2. Average stem (\%), bark (\%) and harvester efficiency (\%) in relation to displacement velocity and absence or presence of the scrapping plate on narrow row cotton harvest in the experiments at Serra da Petrovina (2013/2014), Sorriso (2013/2014), and Sorriso (2014/2015).

\begin{tabular}{|c|c|c|c|c|c|c|c|}
\hline \multicolumn{8}{|c|}{ Serra da Petrovina - MT, (2013/2014) } \\
\hline Velocity $\left(\mathrm{m} \mathrm{s}^{-1}\right)$ & Bark & Stem & Efficiency & Plate & Bark & Stem & Efficiency \\
\hline 0.61 & $0.36 \mathrm{a}$ & $1.25 \mathrm{a}$ & $87.48 \mathrm{a}$ & \multirow{3}{*}{$\begin{array}{l}\text { Absence } \\
\text { Presence }\end{array}$} & \multirow{3}{*}{$\begin{array}{l}0.30 \mathrm{~b} \\
0.44 \mathrm{a}\end{array}$} & \multirow{3}{*}{$\begin{array}{l}1.18 \mathrm{a} \\
1.18 \mathrm{a}\end{array}$} & \multirow{3}{*}{$\begin{array}{l}88.16 \mathrm{a} \\
87.91 \mathrm{a}\end{array}$} \\
\hline 1.0 & $0.37 \mathrm{a}$ & $1.11 \mathrm{a}$ & $88.41 \mathrm{a}$ & & & & \\
\hline 1.42 & $0.37 \mathrm{a}$ & $1.18 \mathrm{a}$ & $87.81 \mathrm{a}$ & & & & \\
\hline \multicolumn{8}{|c|}{ Sorriso - MT, (2013/2014) } \\
\hline Velocity $\left(\mathrm{m} \mathrm{s}^{-1}\right)$ & Bark & Stem & Efficiency & Plate & Bark & Stem & Efficiency \\
\hline 0.61 & $0.32 \mathrm{a}$ & $1.46 \mathrm{a}$ & $90.10 \mathrm{a}$ & \multirow{3}{*}{$\begin{array}{l}\text { Absence } \\
\text { Presence }\end{array}$} & & \multirow{3}{*}{$\begin{array}{l}1.14 \mathrm{a} \\
1.78 \mathrm{~b}\end{array}$} & \multirow{3}{*}{$\begin{array}{l}90.38 \mathrm{a} \\
87.91 \mathrm{~b}\end{array}$} \\
\hline 1.0 & $0.32 \mathrm{a}$ & $1.56 \mathrm{a}$ & $87.22 \mathrm{a}$ & & $0.38 \mathrm{~b}$ & & \\
\hline 1.42 & $0.36 \mathrm{a}$ & $1.40 \mathrm{a}$ & $90.10 \mathrm{a}$ & & & & \\
\hline \multicolumn{8}{|c|}{ Sorriso - MT, $(2014 / 2015)$} \\
\hline Velocity $\left(\mathrm{m} \mathrm{s}^{-1}\right)$ & Bark & Stem & Efficiency & Plate & Bark & Stem & Efficiency \\
\hline 0.61 & $0.33 \mathrm{a}$ & $2.17 \mathrm{~b}$ & $92.55 \mathrm{a}$ & \multirow{3}{*}{$\begin{array}{l}\text { Absence } \\
\text { Presence }\end{array}$} & \multirow{3}{*}{$\begin{array}{l}0.37 \mathrm{a} \\
0.39 \mathrm{a}\end{array}$} & \multirow{3}{*}{$\begin{array}{l}2.16 \mathrm{a} \\
2.65 \mathrm{~b}\end{array}$} & \multirow{3}{*}{$\begin{array}{l}93.08 \mathrm{a} \\
92.28 \mathrm{a}\end{array}$} \\
\hline 1.0 & $0.37 \mathrm{a}$ & $2.40 \mathrm{ab}$ & $92.90 \mathrm{a}$ & & & & \\
\hline 1.42 & $0.44 \mathrm{a}$ & $2.65 \mathrm{a}$ & $92.59 \mathrm{a}$ & & & & \\
\hline
\end{tabular}

Average values followed by the same letter, on the vertical columns, do not statistically differ between each other according to Tukey's test at 5\% probability.

MIC decreased when the scraping plate was used, possibly because of the characteristics of the cotton variety and the quantity of the closed and semi-open (immature) bolls, which may have significantly altered the overall maturity of the fibers, resulting in a low MIC. Similarly, Kerby et al. (1986) found that sampling methods showed more pronounced differences during years of adverse growing conditions. Faulkner et al. (2008) reported that there were no significant differences in SFC and visible foreign matter between harvesting treatments 2007, although the SFC was lower in 2006.

The IU is the ratio between the mean length (ML) and the average length of half of the longer fibers (UHM), expressed as a percentage. This percentage represents the homogeneity of the fiber lengths. A higher UI indicates more uniform lengths, which are better for weaving (AMPA, 2014). According to standard (ASTM D1447, 1995), the UI found in this study was high ( 83 to $85 \%$ ) and, according to the Normative Instruction No. 63 of December 5, 2002 from MAPA (BRASIL, 2002), the UI both in the absence $(83.59 \%)$ and in the presence of scraping plates $(84.36 \%)$ was also high (Table 3 ). Faulkner et al. (2011) evaluated mechanized harvesting systems with a picker platform and observed UI values of $80.4 \%$, showing that the speed does not influence the intrinsic properties of the cotton fiber quality, in years with ideal growing conditions.

For the Sorriso region 2013/2014 crop, UHM, Area, STR, +b, SFC, MIC, IU, and Rd, were not significantly related to the displacement speed or the presence/absence of scraping plates (Table 4). In the 2014/2015 crop, UHM, Area, STR, +b, SFC, MIC, IU, and Rd were not significantly related to the displacement speed or the presence/absence of scraping plates (Table 5). 
Table 3. Average Micronaire index (Mic), Fiber length uniformity index (UI), Upper half mean fiber length (UHM), surface area covered by trash in relation to the total sampling area (Area), Fiber strength (STR), Yellowness index $(+b)$, Short fiber content (SFC) and Degree of reflectance of the fibers (Rd) in relation to the absence or presence of scraping plates and displacement velocity at Serra da Petrovina (2013/2014).

\begin{tabular}{|c|c|c|c|c|c|c|c|c|}
\hline Plate & Mic & UI (\%) & $\begin{array}{l}\text { UHM } \\
(\mathbf{m m})\end{array}$ & $\begin{array}{l}\text { Area } \\
(\%)\end{array}$ & $\begin{array}{l}\text { STR } \\
\text { (gf/tex) }\end{array}$ & $+\mathbf{b}$ & SFC & $\begin{array}{l}\text { Rd } \\
(\%) \\
\end{array}$ \\
\hline Absence & $3.96 \mathrm{a}$ & $83.59 \mathrm{~b}$ & $29.21 \mathrm{a}$ & $0.81 \mathrm{a}$ & $29.87 \mathrm{a}$ & $8.60 \mathrm{a}$ & $8.18 \mathrm{a}$ & $76.67 \mathrm{a}$ \\
\hline Presence & $3.86 \mathrm{~b}$ & $84.36 \mathrm{a}$ & $29.46 \mathrm{a}$ & $0.65 \mathrm{a}$ & $30.20 \mathrm{a}$ & $8.52 \mathrm{a}$ & $7.81 \mathrm{a}$ & $76.80 \mathrm{a}$ \\
\hline Velocity & Mic & $\begin{array}{l}\text { UI } \\
(\%)\end{array}$ & $\begin{array}{l}\text { UHM } \\
(\mathbf{m m})\end{array}$ & $\begin{array}{l}\text { Area } \\
(\%)\end{array}$ & $\begin{array}{l}\text { STR } \\
\text { (gf/tex) }\end{array}$ & $+\mathbf{b}$ & SFC & $\begin{array}{l}\text { Rd } \\
(\%)\end{array}$ \\
\hline V1 & $3.91 \mathrm{a}$ & $83.74 \mathrm{a}$ & $29.21 \mathrm{a}$ & $0.67 \mathrm{a}$ & $30.23 \mathrm{a}$ & $8.55 \mathrm{a}$ & $8.19 \mathrm{a}$ & $76.81 \mathrm{a}$ \\
\hline V2 & $3.92 \mathrm{a}$ & $84.19 \mathrm{a}$ & $29.46 \mathrm{a}$ & $0.62 \mathrm{a}$ & $29.79 \mathrm{a}$ & $8.56 \mathrm{a}$ & $7.77 \mathrm{a}$ & $77.25 \mathrm{a}$ \\
\hline V3 & $3.91 \mathrm{a}$ & 83.99 a & $29.46 \mathrm{a}$ & $0.90 \mathrm{a}$ & $30.07 \mathrm{a}$ & $8.58 \mathrm{a}$ & $8.02 \mathrm{a}$ & $76.14 \mathrm{a}$ \\
\hline
\end{tabular}

Average values followed by the same letter on the vertical columns do not statistically differ between each other according to Tukey's test at $5 \%$ probability.

Tabela 4. Average Micronaire index (Mic), Fiber length uniformity index (UI), Upper half mean fiber length (UHM), surface area covered by trash in relation to the total sampling area (Area), Fiber strength (STR), Yellowness index $(+b)$, Short fiber content (SFC) and Degree of reflectance (Rd) in relation to the absence or presence of scraping plates and displacement velocity at Sorriso (2013/2014).

\begin{tabular}{|c|c|c|c|c|c|c|c|c|}
\hline Plate & $\begin{array}{l}\text { UHM } \\
(\mathbf{m m})\end{array}$ & $\begin{array}{l}\text { Area } \\
(\%)\end{array}$ & $\begin{array}{l}\text { STR } \\
\text { (gf/tex) }\end{array}$ & $+\mathbf{b}$ & SFC & MIC & $\begin{array}{l}\text { UI } \\
(\%)\end{array}$ & $\begin{array}{l}\text { Rd } \\
(\%)\end{array}$ \\
\hline Absence & $26.92 \mathrm{a}$ & $1.28 \mathrm{a}$ & $28.24 \mathrm{a}$ & $9.20 \mathrm{a}$ & $8.87 \mathrm{a}$ & $3.96 \mathrm{a}$ & $81.70 \mathrm{a}$ & $75.88 \mathrm{a}$ \\
\hline Presence & $26.41 \mathrm{a}$ & $1.13 \mathrm{a}$ & $28.33 \mathrm{a}$ & $9.04 \mathrm{a}$ & $9.59 \mathrm{a}$ & $3.92 \mathrm{a}$ & $81.21 \mathrm{a}$ & $75.89 \mathrm{a}$ \\
\hline Velocity & $\begin{array}{l}\text { UHM } \\
(\mathbf{m m})\end{array}$ & $\begin{array}{l}\text { Area } \\
(\%)\end{array}$ & $\begin{array}{l}\text { STR } \\
\text { (gf/tex) }\end{array}$ & $+\mathbf{b}$ & SFC & MIC & $\begin{array}{l}\text { UI } \\
(\%)\end{array}$ & $\begin{array}{l}\text { Rd } \\
\text { (\%) }\end{array}$ \\
\hline V1 & $26.92 \mathrm{a}$ & $1.30 \mathrm{a}$ & $28.28 \mathrm{a}$ & $9.07 \mathrm{a}$ & $8.69 \mathrm{a}$ & $4.04 \mathrm{a}$ & $81.76 \mathrm{a}$ & $75.16 \mathrm{a}$ \\
\hline V2 & $26.67 \mathrm{a}$ & $1.15 \mathrm{a}$ & $28.18 \mathrm{a}$ & $9.23 \mathrm{a}$ & $9.41 \mathrm{a}$ & $3.85 \mathrm{a}$ & $81.00 \mathrm{a}$ & $76.79 \mathrm{a}$ \\
\hline V3 & $26.67 \mathrm{a}$ & $1.16 \mathrm{a}$ & $28.39 \mathrm{a}$ & $9.06 \mathrm{a}$ & $9.59 \mathrm{a}$ & $3.93 \mathrm{a}$ & $81.61 \mathrm{a}$ & $75.71 \mathrm{a}$ \\
\hline
\end{tabular}

Average values followed by the same letter, on the vertical columns, do not statistically differ between each other according to Tukey's test at $5 \%$ probability.

Tabela 5. Average Micronaire index (Mic), Fiber length uniformity index (UI), Upper half mean fiber length (UHM), surface area covered by trash in relation to the total sampling area (Area), Fiber strength (STR), Yellowness index $(+b)$, Short fiber content (SFC) and Degree of reflectance (Rd) in relation to the absence or presence of scraping plates and displacement velocity at Sorriso (2014/2015).

\begin{tabular}{|c|c|c|c|c|c|c|c|c|}
\hline Plate & $\begin{array}{l}\text { UHM } \\
(\mathbf{m m})\end{array}$ & $\begin{array}{l}\text { Area } \\
(\%)\end{array}$ & $\begin{array}{l}\text { STR } \\
\text { (gf/tex) }\end{array}$ & $+\mathbf{b}$ & SFC & MIC & $\begin{array}{l}\text { UI } \\
(\%)\end{array}$ & $\begin{array}{l}\text { Rd } \\
(\%)\end{array}$ \\
\hline Absence & $28.95 \mathrm{a}$ & $1.34 \mathrm{a}$ & $26.23 \mathrm{a}$ & $8.22 \mathrm{a}$ & $9.18 \mathrm{a}$ & $3.25 \mathrm{a}$ & $82.10 \mathrm{a}$ & $74.62 \mathrm{a}$ \\
\hline Presence & $28.70 \mathrm{a}$ & $1.23 \mathrm{a}$ & $26.66 \mathrm{a}$ & $8.39 \mathrm{a}$ & $9.25 \mathrm{a}$ & $3.17 \mathrm{a}$ & $82.10 \mathrm{a}$ & $75.10 \mathrm{a}$ \\
\hline Velocity & $\begin{array}{l}\text { UHM } \\
(\mathbf{m m})\end{array}$ & $\begin{array}{l}\text { Area } \\
(\%)\end{array}$ & $\begin{array}{l}\text { STR } \\
\text { (gf/tex) }\end{array}$ & $+\mathbf{b}$ & SFC & MIC & $\begin{array}{l}\text { UI } \\
(\%)\end{array}$ & $\begin{array}{l}\text { Rd } \\
(\%)\end{array}$ \\
\hline V1 & $28.70 \mathrm{a}$ & $1.36 \mathrm{a}$ & $26.39 \mathrm{a}$ & $8.22 \mathrm{a}$ & $8.93 \mathrm{a}$ & $3.18 \mathrm{a}$ & $82.11 \mathrm{a}$ & $74.61 \mathrm{a}$ \\
\hline V2 & $29.21 \mathrm{a}$ & $1.28 \mathrm{a}$ & $26.67 \mathrm{a}$ & $8.46 \mathrm{a}$ & $9.11 \mathrm{a}$ & $3.20 \mathrm{a}$ & $82.39 \mathrm{a}$ & $75.51 \mathrm{a}$ \\
\hline V3 & $28.70 \mathrm{a}$ & $1.22 \mathrm{a}$ & $26.27 \mathrm{a}$ & $8.24 \mathrm{a}$ & $9.60 \mathrm{a}$ & $3.24 \mathrm{a}$ & $81.79 \mathrm{a}$ & $74.45 \mathrm{a}$ \\
\hline
\end{tabular}

Average values followed by the same letter, on the vertical columns, do not statistically differ between each other according to Tukey's test at $5 \%$ probability. 


\section{Conclusion}

The scraping plates increased the number of stems and cones and reduced the harvest efficiency of dense cotton in the Sorriso-MT region, during the 2013/2014 harvest. For the 2014/2015 harvest, the highest speed and the presence of the scraping plates increased the number of cones in the seed cotton samples. In the experiment carried out in Serra da Petrovina, the removal of the scraping plates decreased the number of cones in the harvested cotton. In all regions, crop efficiency was below that which is recommended and farmers are suffering high losses. Further studies are necessary to determine which specific issues are contributing to these losses.

\section{Acknowledgements}

The authors are grateful to the Instituto Matogrossente de Algodão (IMAmt) for the financial support to this research and by assistance during the development of the study.

\section{References}

ALVAREZ, G.; BASTO, H.; SIERRA, J. F. Recolección. In: FEDERACIÓN NACIONAL DE ALGODONEROS. Bases técnicas para el cultivo del algodón en Colombia. Bogotá: Guadalupe, 1990. p. 609-632

\section{ASSOCIAÇÃO MATOGROSSENSE DOS} PRODUTORES DE ALGODÃO - AMPA. Manual de beneficiamento do algodão. 2. ed. Cuiabá: Editora Casa da Árvore, 2014. 27 p.

AMERICAN SOCIETY FOR TESTING AND
MATERIALS. - ASTM D4605-86. Test Method
for Measurement of Cotton Fibers by High Volume
Instruments (HVI): Special Instruments Laboratory
System. West Conshohocken, 1995. 9 p. Disponível
em: <http://www.astm.org/DATABASE.CART/
WITHDRAWN /D4605.htm>. Acesso em: 02 ago. 2015.

BAKER, R. V.; ANTHONY, W. S.; SUTTON, R. N. Seed cotton cleaning and extracting. In: ANTHONY, W. S.; MAYFIELD, W. D. Cotton ginners handbook. Washington: USDA, 1994. p. 69-90. (USDA. Agricultural Handbook Number, 503).
BELOT, J. L.; VILELA, P. M. C. A. Colheita de algodão. In: FACUAL - Fundo de Apoio à Pesquisa do Algodão. Algodão: pesquisas e resultados para o campo. Cuiabá: FACUAL, 2006. 390 p.

BRASIL. Instrução Normativa $\mathrm{n}^{\circ} 63$, de 5 de dezembro de 2002. Aprova o regulamento técnico de identidade e de qualidade para a classificação do algodão em pluma. Diário Oficial [da] União, Brasília, 6 dez. 2002. Seção 1, p. 6-8.

BRUNETA, E. Estratégias de colheita e beneficiamento para fibra de alta qualidade. In: CONGRESSO BRASILEIRO DE ALGODÃO, 5., 2005, Campina Grande. Anais... Campina Grande: Embrapa, CNPA, 2005. 1 CD-ROM.

CHANSELME, J.; RIBAS, P. V. Beneficiamento do algodão adensado e qualidade da fibra. In: IMAMT. Instituto Mato-Grossense do Algodão. O Sistema de cultivo do algodoeiro adensado em Mato Grosso. Cuiabá: Editora Defanti, 2010. 390 p.

COMPANHIA NACIONAL DE ABASTECIMENTO - CONAB. Acompanhamento de safra brasileira: grãos safra 2012/2013, décimo levantamento, julho 2014. Brasília, DF: CONAB, 2014. 38 p.

FAIRCLOTH, J. C.; HUTCHINSON, R.; BARNETT, J.; PAXSON, K.; COCO, A.; PRICE III, P. An evaluation of alternative cotton harvesting methods in Northeast Louisiana: a comparison of the brush stripper and spindle harvester. Journal of Cotton Science, Baton Rouge, v. 8 , n. 2, p. 55-61, 2004

FAULKNER, W. B.; SHAW, B. W.; HEQUET, E. Effects of harvesting method on foreign matter content, fiber quality, and yarn quality from irrigated cotton on the high plains. American Society of Agricultural and Biological Engineers (ASABE), St. Joseph, 2008. p. 612-619.

FAULKNER, W. B.; WANJURA, E. F.; HEQUET, E. F.; BOMAN, R. K.; SHAW, B. W.; PARNELL JUNIOR, C. B. Evaluation of modern cotton harvest systems on irrigated cotton: fiber quality. Applied Engineering in Agriculture, St. Joseph, v. 27, n. 4, p. 507-513. 2011.

KERBY, T. A.; HAKE, K.; KEELEY, M. Cotton fruiting modification with mepiquat chloride. Agronomy Journal, Madison, v. 78, n. 5, p. 907-12, 1986.

MANGIALARDI JUNIOR., G. J.; ANTHONY, W. S. Field evaluations of air and saw lint cleaning systems. Journal of Cotton Science, Baton Rouge, v. 2, n. 1, p. 53-61,1998.

RODRIGUEZ, H. E. Caracteristics of cotton strains related to mechanical picker efficiency. 1977. Thesis (Master of Science) - Mississipi State University, Mississipi. 
SILVA, F. A. S. ASSISTAT. Versão 77 beta. Campina Grande: [s.n.], 2014. Disponível em: <http://www. assistat. com.DEAG-CTRN-UFCG>. PB. Acesso em: 01 abr. 2014.

SMITH, C. W.; HAGUE, S.; HEQUET, E.; THAXTON, S.; BROWN, N. Development of extra-long staple upland cotton. Crop Science, Madison, v. 48, n. 5, p. 1823-1832, 2008.
SOFIATTI, V. Sistema de cultivo adensado para o algodoeiro. In: CONGRESSO BRASILEIRO DE ALGODÃO, 8.; COTTON EXPO, 1., 2011, São Paulo: Anais... Campina Grande, PB: Embrapa Algodão, 2011. p. 1740-1745. CD-ROM.

WILLIFORD, J. R.; BRASHEARS, A. D.; BARKER, G. L. Harvesting. In: ANTHONY, W. S.; MAYFIELD, W. D. Cotton ginners handbook. Washington, D.C.: USDA Agricultural Research Service. 1994. p. 11-16. (USDA. Agricultural Handbook Number, 503). 
